\title{
Proximal Tubular Epithelial Cell Integrins Respond to High Glucose by Altered Cell-Matrix Interactions and Differentially Regulate Matrixin Expression
}

\author{
Panagiotis M. Karamessinis, Athina K. Tzinia, Paraskevi V. Kitsiou, \\ William G. Stetler-Stevenson, Alfred F. Michael, Wei-Wei Fan, Bing Zhou, \\ Lukas H. Margaritis, and Effie C. Tsilibary \\ Institute of Biology (PMK, AKT, PVK, ECT), National Center for Scientific Research "Demokritos," and Faculty of \\ Biology (LHM), Department of Cell Biology and Biophysics, University of Athens, Panepistimiopolis, Athens, \\ Greece; Laboratory of Pathology (WGS-S), NCI, National Institutes of Health, Bethesda, Maryland; and Department \\ of Pediatrics (AFM, W-WF, BZ), University of Minnesota Medical School, Minneapolis, Minnesota
}

\begin{abstract}
SUMMARY: Thickening of the tubular basement membrane (TBM) occurs in diabetic nephropathy, but the effects of high glucose on the functional aspects of proximal tubular epithelial cells are not clearly understood. In the present study, we examined the effects of elevated glucose concentrations on (a) integrin expression by human proximal tubular epithelial cells (HK-2) and integrin-mediated interactions with type IV collagen (collV) and laminin, major components of TBM; (b) the expression of matrixins/matrix metalloproteinases (MMPs), which is regulated by integrins; and (c) the expression of tissue inhibitors of metalloproteinases (TIMPs). HK-2 cells cultured in 25 mM glucose underwent a reduction of the expression of $\alpha 3, \beta 1, \alpha \mathrm{v} \beta 3$, and $\alpha 5$ integrin subunits, with a concomitant increase of the $\alpha 2$ subunit, compared with cells grown in 5 mm glucose. Adhesion experiments demonstrated that high glucose led to increased cell adhesion on either collV or laminin. Experiments of competition of adhesion using anti-integrin antibodies indicated that HK-2 cells in $5 \mathrm{~mm}$ glucose used mainly $\alpha \mathrm{V} \beta 3$ and $\alpha 5 \beta 1$ integrins to adhere to collV, whereas in $25 \mathrm{~mm}$ glucose they additionally used $\alpha 2 \beta 1$. In the case of laminin, a $\beta 1$-mediated adhesion was observed when HK-2 cells were in $5 \mathrm{~mm}$ glucose, whereas in $25 \mathrm{~mm}$ glucose, $\alpha 2 \beta 1$ and $\alpha \mathrm{v} \beta 3$ were also involved. Elevated glucose concentrations resulted in decreased expression of MMP-9 and MMP-2, whereas an increase in TIMP-1 and a decrease in TIMP-2 expression were observed. We also examined which integrins mediated the expression and secretion of matrixins MMP-2 and MMP-9. Ligation of $\alpha 3 \beta 1$ with mAbs resulted in induction of MMP-2 expression and secretion, whereas antibody ligation of $\alpha \vee \beta 3$ led to down-regulation of MMP-9. The above data implicate integrins of proximal tubular epithelial cells in the regulation of MMPs and in the development of TBM thickening in diabetic nephropathy. (Lab Invest 2002, 82:1081-1093).
\end{abstract}

$B^{2}$ asement membranes (BM) are specialized extracellular matrices (ECM) composed mainly of type IV collagen (collV), laminin, entactin, and proteoglycans, which are considered to influence cellular phenotype and function (Paulsson, 1992). Interactions between cells and ECM are mediated by cell surface receptors, including integrins. Integrins are transmembrane receptors composed of two subunits, $\alpha$ and $\beta$, that heterodimerize in noncovalent association (Hynes, 1992; Ruoslahti, 1991). Each dimer can recognize several ECM proteins and each protein can bind with more than one dimer. On binding to ECM, integrins become clustered to the cell membrane, leading to the formation of focal adhesions where

DOI: 10.1097/01.LAB.0000022224.86237.31

Received April 25, 2002.

Supported by National Institutes of Health (Grant AI0708) and by the Greek GSRT/PENED-99 (Grant 174ED).

Address reprint requests to: Dr. Effie C. Tsilibary, Institute of Biology, National Center for Scientific Research "Demokritos", 15310 Agia

Paraskevi, Athens, Greece.E-mail: effie@mail.demokritos.gr integrins link with the cytoskeleton. Focal adhesions also serve as a point for the activation of several signal transduction events (Boudreau and Jones, 1999; Chen et al, 1994; Clark and Brugge, 1995; Giancotti and Ruoslahti, 1999; Juliano and Haskill, 1993; Schlaepfer et al, 1994). Thus, integrins can transduce signals from the ECM to the cell interior that regulate various cellular functions, including adhesion, migration, proliferation, and gene expression (Boudreau and Jones, 1999; Clark and Brugge, 1995; Giancotti and Ruoslahti, 1999).

Diabetic nephropathy (DN) is a major complication in diabetes (Mauer et al, 1984), characterized by structural changes, including thickening of the glomerular (GBM) and tubular basement membranes (TBM), as well as expansion of the mesangial matrix (MM) (Brito et al, 1998; Lane et al, 1993; Rasch, 1984; Steffes et al, 1989, 1992; Ziyadeh, 1993).

Structural changes, which occur in diabetes, are due to increased deposition (synthesis and accumulation) and/or decreased degradation of ECM macromolecules. Studies have demonstrated that high glucose levels in vitro lead to increased expression and 
accumulation of ECM proteins in different renal cells (Anderson et al, 1996; Ayo et al, 1990, 1991; Danne et al, 1993; Phillips et al, 1997; Roth et al, 1993). Altered matrix expression in kidneys has also been observed in streptozotocin-diabetic rats (Wu et al 1997). In addition, nonenzymatic glycation (NEG) of BM proteins was reported to alter their structure and function in vitro (Anderson et al, 1992, 1993; Charonis and Tsilibary, 1992; Tsilibary et al, 1988), as well as interactions of these proteins with mesangial, endothelial, and glomerular epithelial cells (Anderson et al, 1994; Haitoglou et al, 1992; Krishnamurti et al, 1997).

Remodeling and degradation of ECM is mediated by matrixins (matrix metalloproteinases: MMPs), a family of zinc-dependent endopeptidases, which are involved in matrix turnover, in normal and disease processes (Birkedal-Hansen, 1995; Nagase and Woessner, 1999; Werb, 1997). For example, gelatinase A (72-kd gelatinase, or MMP-2) and B (92-kd gelatinase, or MMP-9) degrade collagen types IV, V, VII, and IX, gelatin, elastin, and fibronectin (BirkedalHansen, 1995; Matrisian, 1992). Matrixins are synthesized as proenzymes, secreted in an inactive form (proMMPs), and their proteolytic activities are controlled by inhibitors and activators. Proteolytic processing and activation of gelatinases may occur through their own proteolytic cleavage by other MMPs or proteases and, in addition, membrane-type MMPs (MT-MMPs) can activate proMMP-2 on the cell surface (Matrisian, 1992; Nagase and Woessner, 1999; Werb, 1997). Most cells express and secrete tissue inhibitors of metalloproteinases (TIMPs), TIMP-1 and TIMP-2, which preferentially bind MMP-9 and MMP-2, respectively (Matrisian, 1992; Nagase and Woessner, 1999; Werb, 1997). Integrins have been/shown to mediate the expression of MMPs in various cell types (Ellerbroek et al, 1999; Langholz et al, 1995; Larjava et al, 1993; Seftor et al, 1992, 1993; Werb et al, 1989; Xie et al, 1998). In addition, cell surface proteolysis by MMPs may involve integrins directly (Brooks et al, 1996). Hence, integrins regulate matrix-related gene expression at least in part.

Different culture conditions may result in either enhanced or decreased expression of integrin receptors, in various physiologic and pathologic processes (Adams and Watt, 1990; Rozzo et al, 1993). For example, cells cultured in increased glucose concentrations were shown to undergo changes in integrin expression. Modulation of integrin expression resulted in altered adhesion to ECM proteins (Kitsiou et al, unpublished data; Roth et al, 1993; Setty et al, 1995).

In the present study we have used HPV-16 immortalized human proximal tubular epithelial cells (HK-2), to understand the mechanisms leading to TBM thickening, which occurs in DN, in addition to thickening of the GBM. HK-2 cells retain functional and morphologic characteristics of normal adult human proximal tubular epithelium (Ryan et al, 1994). We have examined the cellular and surface expression of integrin receptors in HK-2 cells cultured in normal and elevated glucose concentrations, and functional aspects of these cells related to integrins, including integrin- mediated interactions between cells and matrix macromolecules, such as collV and laminin; and the expression and secretion of MMPs and TIMPs, proteins involved in basement membrane turnover. We present evidence that in $\mathrm{HK}-2$ cells, the $\alpha 3 \beta 1$ integrin is a major receptor responsible for the induction of MMP-2 expression, whereas the $\alpha \mathrm{v} \beta 3$ integrin mediates down-regulation of MMP-9 in this system.

\section{Results}

Because integrin expression and function in diabetes might play a role in the development of related complications such as DN, we first examined the effect of high glucose concentration on the expression of integrins in HK-2 cells. Exposure of HK-2 cells to $25 \mathrm{~mm}$ glucose resulted in a decrease of $\alpha 3$ and $\beta 1$ integrin mRNA levels by $30 \%$ and $36 \%$, respectively, compared with cells grown in $5 \mathrm{~mm}$ glucose (Fig. 1). The glucose-induced decrease in mRNA of the examined integrin subunits was accompanied by decreased protein synthesis. Cells grown in $25 \mathrm{~mm}$ expressed $25 \%$ less $\alpha 3$ and $31 \%$ less $\beta 1$ integrins (Fig. 2). In addition, Western blot analysis of $\alpha 2, \alpha 5, \alpha \mathrm{v}$, and $\beta 3$ integrin revealed that cells cultured in $25 \mathrm{~mm}$ glucose expressed $24 \%$ less $\alpha 5,15 \%$ less $\alpha \mathrm{v}, 20 \%$ less $\beta 3$, and $29 \%$ more $\alpha 2$ integrins compared with control cells (Fig. 2).
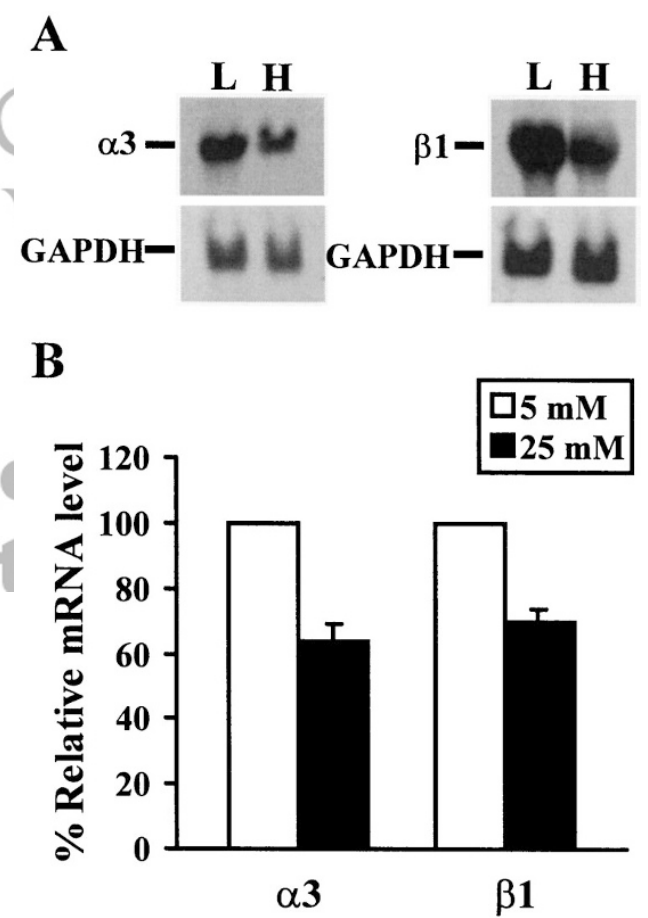

Figure 1.

Northern blot analysis of $\alpha 3$ and $\beta 1$ integrin mRNA from HK-2 cells cultured in low or high glucose. A, Total RNA was isolated from cells cultured in $5 \mathrm{~mm}$ $(L)$ or $25 \mathrm{~mm}(H)$ glucose. Twenty micrograms of each sample were probed with $\alpha 3$ and $\beta 1$ DIG-labeled CDNA. Filters were rehybridized with a CDNA probe for glyceraldehyde-3-phosphate dehydrogenase (GAPDH), as internal control, to verify RNA loads. B, Densitometric analysis of the mRNA level probed in A. Expression in $5 \mathrm{~mm}$ glucose was plotted as 100\%. Each bar represents the mean \pm standard deviation of three independent experiments. Differences were significant at $p<0.05$. 


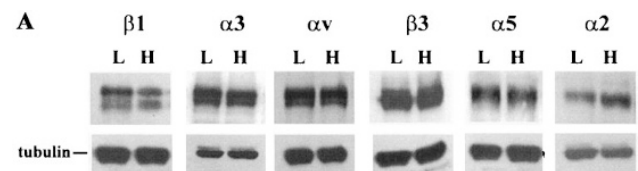

B

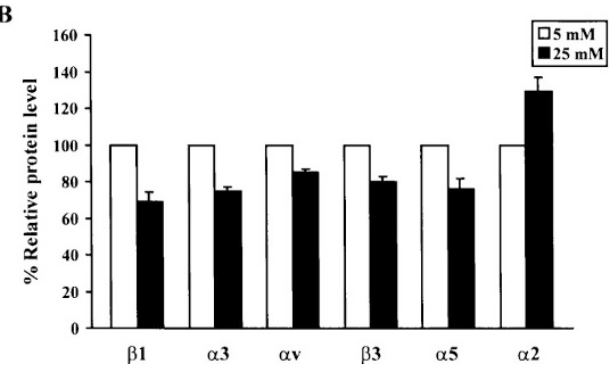

Figure 2.

Western blot analysis of integrin expression in HK-2 cells cultured in low or high glucose. A, Total protein was extracted from cells cultured in either $5 \mathrm{~mm}$ $(L)$ or $25 \mathrm{~mm}(H)$ glucose. Equal amounts of total protein were analyzed on $7.5 \%$ SDS-PAGE under nonreducing conditions and immunoblotted with the appropriate dilution of polyclonal antibodies against integrin subunits. Blots were stripped and reprobed with anti-tubulin antibody, to verify protein loads, to which all quantitative data were normalized. B, Quantification of the protein content of each integrin subunit by scanning densitometry. Expression in $5 \mathrm{~mm}$ glucose was plotted as $100 \%$. Each bar represents the mean \pm standard deviation (SD) of three independent experiments. Differences were significant at $p<0.05$

We additionally used flow cytometry to determine whether glucose altered integrin expression on the cell surface. Specific mAbs against $\alpha 3, \alpha 2, \alpha \vee \beta 3$, and $\beta 1$ integrins were used as primary antibodies. As a control, we have used an anti-HLA mAb. As shown in Figure 3 , exposure of cells to $25 \mathrm{~mm}$ glucose resulted in a significant decrease of cell surface-associated $\alpha \vee \beta 3$ integrin. In addition, there was a similar decrease in the amount of cell surface $\alpha 3$ and $\beta 1$ subunits in cells grown in $25 \mathrm{~mm}$, compared with cells grown in 5 $\mathrm{mm}$ glucose. There was no effect on cell surface expression of the $\alpha 2$ integrin subunit, although there was a significant increase in the number of cells (approximately $40 \%$ ) that were positive for this subunit in the presence of $25 \mathrm{~mm}$ glucose (data not shown).

Because integrin receptors play an important role in cell-matrix interactions, we examined the effects of glucose on the ability of HK-2 cells to adhere to collV and laminin, which are both components of their native TBM. Cells grown in either low $(5 \mathrm{~mm})$ or high (25 mM) glucose were allowed to adhere for $60 \mathrm{~min}-$ utes to Engelbreth-Holm-Swarm (EHS)-derived collV and laminin. Cells exposed to high glucose adhered more, both to collV (Fig. 4A) and laminin (Fig. 4B), than cells grown in low glucose. The adhesion to both substrates was concentration-dependent up to 50 $\mu \mathrm{g} / \mathrm{ml}$, which represented the maximal observed adhesion. In addition, the data presented in Figure 4 suggest that HK-2 cells prefer collV as a substrate, reaching up to $30 \%$ adhesion in $5 \mathrm{~mm}$ glucose, compared with $19 \%$ maximal adhesion to laminin. This preference was sustained in the presence of high glucose; up to $32 \%$ of HK-2 cells adhered to collV and $22 \%$ adhered to laminin. Differences in adhesion to both substrates, in the presence of high glucose
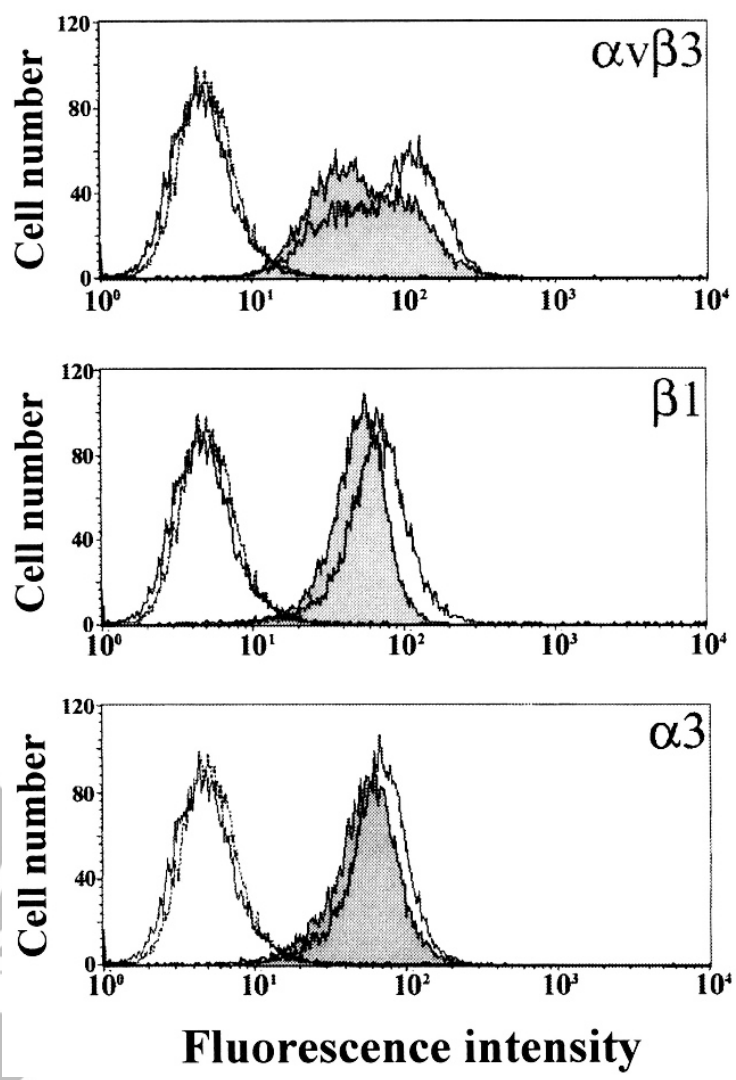

Figure 3.

FACS analysis of HK-2 cell-surface integrin expression. HK-2 cells cultured in media containing $5 \mathrm{~mm}$ (unshaded) or $25 \mathrm{~mm}$ (shaded) glucose were incubated with $\mathrm{mAbs}$ to $\alpha 3$ (P1B5), $\beta 1$ (P5D2), and $\alpha \vee \beta 3$ (Lm609) integrins, for 45 minutes on ice. Cells incubated in the absence of antibody or in the presence of anti-HLA mAb (W6/32) were used as negative or positive controls respectively. FITC-conjugated anti-mouse IgG was used as a secondary antibody. The first peaks (unshaded) represent cells incubated in the absence of primary antibody.

compared with low glucose, were statistically significant $(p<0.05)$ in all but the highest two concentrations, in the case of collV.

To examine the functional role of different integrin subunits in the binding of HK-2 cells to collV and laminin under conditions of low and high glucose, we tested the adhesion of these cells to collV and laminin in the presence of various blocking anti-integrin antibodies (Fig. 5, A and B). Antibodies were used at saturating concentrations, as determined by flow cytometry. In competition experiments, to achieve optimal antibody effects, we selected substrate concentrations that promoted approximately half-maximal binding of HK-2 $(10 \mu \mathrm{g} / \mathrm{ml}$ for collV, and $12 \mu \mathrm{g} / \mathrm{ml}$ for laminin). The data shown in Figure $5 \mathrm{~A}$ indicate that mAbs directed against the $\alpha 2$ (P1E6), $\alpha 5$ (P1D6), $\alpha \vee \beta 3$ (Lm609), and $\beta 1$ (P5D2) integrin subunits competed for the adhesion between HK-2 cells and collV. The $\mathrm{mAb}$ directed against $\alpha 3$ integrin subunit (P1B5) caused cell aggregation and was not effective in blocking adhesion. Adhesion in the presence of different antibodies was shown as the percentage of binding in the absence of antibodies, which was considered maximal (100\%) adhesion, in each case. The 

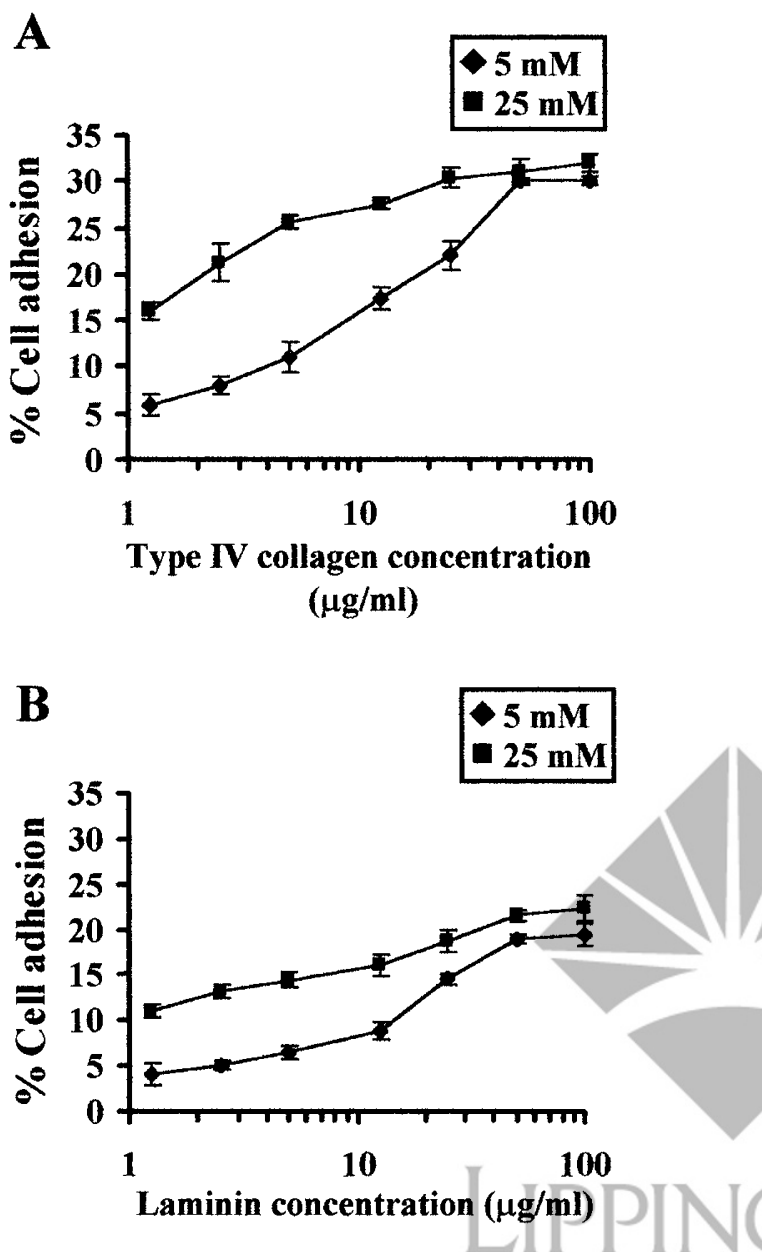

Figure 4.

Adhesion of HK-2 cells to Engelbreth-Holm-Swarm (EHS)-derived type IV collagen (collV) (A) and laminin (B). ${ }^{35} \mathrm{~S}$ - methionine-labeled HK-2 cells cultured in media containing 5 or $25 \mathrm{~mm}$ glucose were seeded in 96-well plates ( 5,000 cells/well) coated with increasing concentrations of collV or laminin, and allowed to adhere for 60 minutes at $37^{\circ} \mathrm{C}$. At the end of the incubation period, nonadherent cells were washed off, adherent cells were lysed, and radioactivity was quantitated. Bound counts were expressed as a percentage of total counts to give percentage adhesion. Nonspecific adhesion of cells to BSA, which was less than $1 \%$, was subtracted from total adhesion in each case. Results were expressed as mean \pm sD of six replicates, from three experiments. Differences were significant at $p<0.05$, except for the highest two concentrations of collV.

extent of inhibition of adhesion by anti- $\alpha 2,-\alpha \vee \beta 3,-\alpha 5$, and $-\beta 1$ antibodies varied depending on glucose concentration. For example, in $5 \mathrm{~mm}$ glucose, anti- $\alpha 2$ antibodies resulted in less inhibition of adhesion ( 15\%) compared with inhibition observed in $25 \mathrm{~mm}$ glucose ( 44\%) (Fig. 5A). This correlated with the observed increase of $\alpha 2$ integrin in HK-2 cells grown in $25 \mathrm{~mm}$, compared with cells grown in $5 \mathrm{~mm}$ glucose. However, in $5 \mathrm{~mm}$ glucose, anti- $\alpha \mathrm{v} \beta 3$ antibodies resulted in more inhibition of adhesion ( 69\%) than in 25 $\mathrm{mm}$ glucose ( 50\%) (Fig. 5A). This was consistent with the observed decrease of $\alpha \mathrm{v} \beta 3$ integrin in cells grown in $25 \mathrm{~mm}$ glucose compared with cells grown in $5 \mathrm{~mm}$ glucose. Anti- $\alpha 5$ and anti- $\beta 1$ antibodies resulted in similar inhibition of adhesion, in either glucose concentration. These data indicate that under low glucose conditions, HK-2 cells primarily used $\alpha \vee \beta 3$ and $\alpha 5 \beta 1$
$\mathbf{A}$
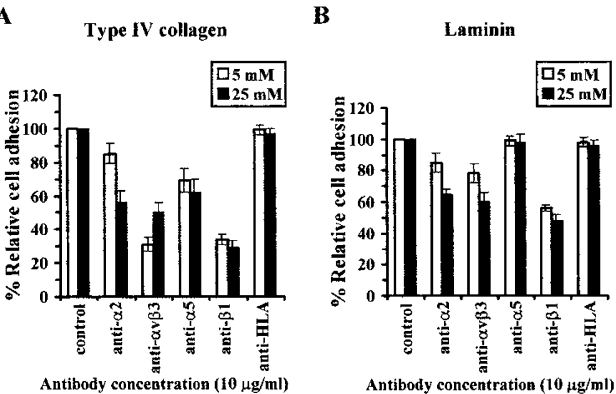

Figure 5

Inhibition of adhesion of HK-2 cells to collV (A) and laminin (B) by anti-integrin antibodies in solid phase binding assays. $\left.{ }^{35} \mathrm{~S}\right]$-methionine-labeled HK-2 cells cultured in media containing 5 or $25 \mathrm{~mm}$ glucose were seeded in 96 -well plates ( 5,000 cells/well) coated with $50 \mu \mathrm{l}$ collV $(10 \mu \mathrm{g} / \mathrm{ml})$ or $50 \mu \mathrm{l}$ laminin (12 $\mu \mathrm{g} / \mathrm{ml})$, and allowed to adhere for 60 minutes at $37^{\circ} \mathrm{C}$. Anti-integrin mAbs anti- $\alpha 2$ (P1E6), anti- $\alpha 5$ (P1D6), anti- $\alpha \vee \beta 3$ (Lm609), and anti- $\beta 1$ (P5D2) were added to the wells at a final concentration of $10 \mu \mathrm{g} / \mathrm{ml}$ before seeding with cells. Adhesion in the absence of $M A b$ or in the presence of anti-HLA mAb (W6/32) was used as negative or positive control, respectively. At the end of the incubation period, nonadherent cells were washed off, adherent cells were lysed, and radioactivity was quantitated. Bound counts were expressed as a percentage of the counts bound in the absence of $\mathrm{mAb}$, in each case. Results were expressed as mean \pm SD of six replicates, from three experiments. Differences were significant at $p<0.05$.

integrins to bind collV, and that $\alpha 2 \beta 1$ participated to a lesser extent in this case. When cells were grown in high glucose, the cells used $\alpha v \beta 3, \alpha 5 \beta 1$, and $\alpha 2 \beta 1$ integrins to a similar extent, to adhere to collV.

When laminin was used as a substrate, mAbs against the $\alpha 2$ and $\alpha v \beta 3$ integrins resulted in less inhibition of adhesion in the presence of $5 \mathrm{~mm}$ glucose ( $15 \%$ and $\sim 22 \%$, respectively) compared with $25 \mathrm{~mm}$ glucose $(\sim 35 \%$ and $\sim 40 \%$, respectively) (Fig. 5B); $\mathrm{mAb}$ against $\beta 1$ integrin resulted in similar inhibition of cell adhesion, in either 5 or $25 \mathrm{~mm}$ glucose $(45 \%$ and $\sim 51 \%$, respectively) (Fig. 5B). mAb against $\alpha 5$ integrin did not inhibit adhesion in either glucose concentration, thus $\alpha 5 \beta 1$ was not involved in the binding of HK-2 cells to laminin. These data suggest that when HK-2 cells were grown in $5 \mathrm{~mm}$ glucose, adhesion to laminin was primarily mediated by a $\beta 1$-bearing integrin, and to a lesser extent by $\alpha \mathrm{v} \beta 3$ integrin. When cells were cultured in $25 \mathrm{~mm}$ glucose, they used $\alpha \mathrm{v} \beta 3$ and additionally $\alpha 2 \beta 1$ to a greater extent compared with cells cultured in $5 \mathrm{~mm}$ glucose. mAb directed against HLA (W6/32), which was used as a control, had no effect on cell adhesion (Fig. 5, A and B).

MMPs are regulated by integrin-mediated pathways and also play a significant role in BM turnover; therefore we examined the presence and activity of MMPs in media from HK-2 cells cultured in 5 and $25 \mathrm{~mm}$ glucose. Using gelatin zymography of the conditioned media from cells, we detected enzymatic activity at two major bands corresponding to MMP-9 (92 kd) and MMP-2 (72 kd) (Fig. 6A). Densitometric analysis showed that conditioned media by HK-2 grown in 25 mM glucose contained $40 \%$ less of the MMP-9 and $39 \%$ less of MMP-2, respectively, compared with cells grown in $5 \mathrm{~mm}$ glucose (Fig. 6B).

In sequence, Northern (Fig. 7, A and B) and Western blot analysis (Fig. 7, C and D) were performed to 
A

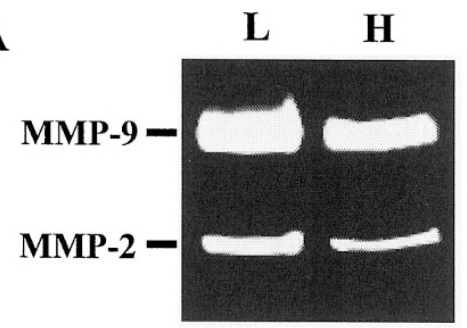

B

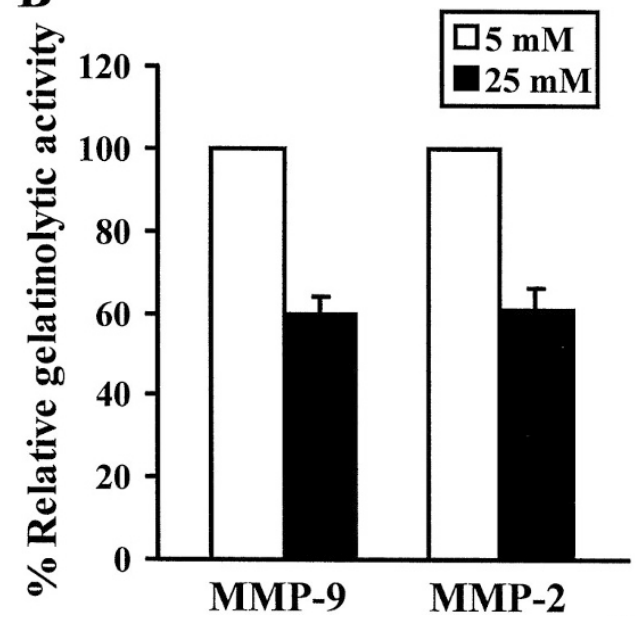

A

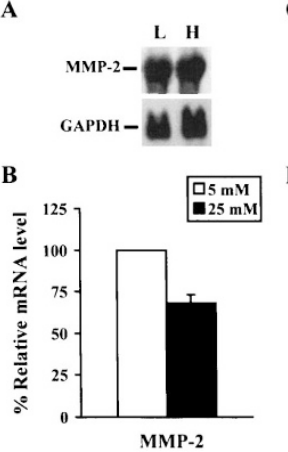

C

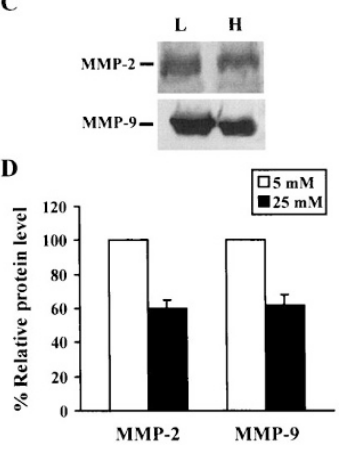

Figure 7.

Effect of glucose on matrixins/matrix metalloproteinases (MMPs) secreted by HK-2 cells. A, Total RNA was isolated from cells cultured in $5 \mathrm{~mm}(\mathrm{~L})$ or $25 \mathrm{~mm}$ (H) glucose. Twenty micrograms of each sample were probed with DIG-labeled cDNA for MMP-2 and rehybridized with a cDNA probe for GAPDH, as internal control, to verify RNA loads. C, Aliquots of equal amounts of conditioned media based on cell numbers from cells cultured in $5 \mathrm{~mm}(\mathrm{~L})$ or $25 \mathrm{~mm}(\mathrm{H})$ glucose, were concentrated and analyzed on $10 \%$ SDS-polyacrylamide gel under reducing conditions. Electrophoretically transferred proteins were immunoblotted using primary antibodies against MMP-2 and MMP-9. Results from both Northern and Western blottings were analyzed by densitometry ( $B$ and $D$, respectively). Expression in $5 \mathrm{~mm}$ glucose was plotted as $100 \%$. Each bar represents the mean \pm SD of three independent experiments. Differences were significant at $p<0.05$.

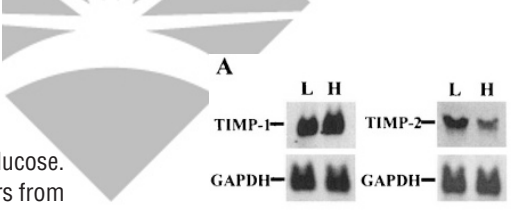

Secretion of MMP-2 and MMP-9 by HK-2 cells cultured in 5 or 25 mm glucose. $A$, Aliquots of equal amounts of conditioned media based on cell numbers from cells cultured in $5 \mathrm{~mm}(L)$ or $25 \mathrm{~mm}(H)$ glucose, were concentrated and analyzed on $10 \%$ SDS-polyacrylamide gel containing $0.1 \%$ gelatin under nonreducing conditions. Gelatinolytic activity was detected as clear bands after incubation in enzyme buffer for 48 hours at $37^{\circ} \mathrm{C}$ and staining with Coomassie brilliant blue. B, Quantitation of the 92-kd form of MMP-9 and 72-kd form of MMP-2, by scanning densitometry. Gelatinolytic activity in $5 \mathrm{~mm}$ glucose was plotted as $100 \%$. Each bar represents the mean \pm SD of three independent experiments. Differences were significant at $p<0.05$.

examine the expression and production of MMP-2 and, in addition, MMP-9 was examined by Western blotting in HK-2 cells cultured in the presence of 5 or $25 \mathrm{~mm}$ glucose. The mRNA of MMP-2 was decreased by $32 \%$ in cells cultured in $25 \mathrm{~mm}$ glucose compared with cells cultured in control $(5 \mathrm{~mm})$ glucose media (Fig. 7, A and B).

Western blot analysis of conditioned media from cells grown in $25 \mathrm{~mm}$ glucose demonstrated $40 \%$ less immunoreactivity at a band corresponding to the 72-kd form of MMP-2 compared with media conditioned by control cells (Fig. 7, C and D). Furthermore, the $92-\mathrm{kd}$ form of MMP-9 was decreased by $38 \%$ in conditioned media from cells cultured in high glucose concentration in comparison with control cells (Fig. 7, C and D).

Because TIMPs regulate the activity of MMPs, we also examined the pattern of TIMPs expressed by cells grown in low and high glucose concentration. Northern blot analysis of TIMPs in cells cultured in 25 mM glucose revealed a 34\% increase in TIMP-1 mRNA level, whereas the level of TIMP-2 mRNA showed a $38 \%$ decrease compared with control cells (Fig. 8, A and $B)$. These changes were corroborated by Western

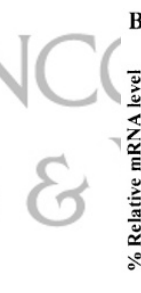

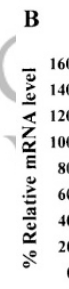
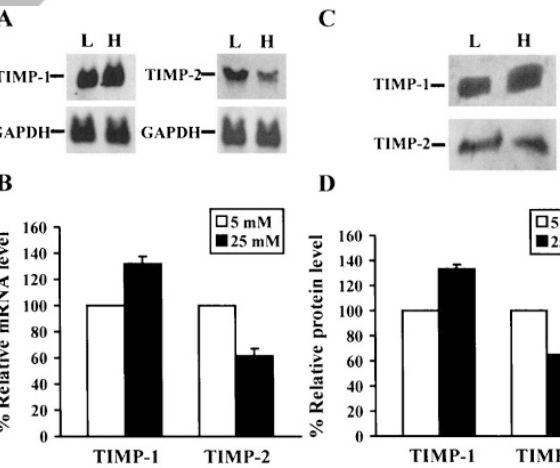

D

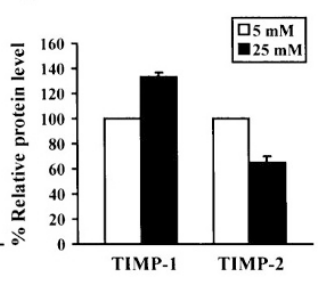

Figure 8.

Effect of glucose on the expression of TIMPs in HK-2 cells. A, Total RNA was isolated from cells cultured in $5 \mathrm{~mm}(L)$ or $25 \mathrm{~mm}(H)$ glucose. Twenty micrograms of each sample were probed with DIG-labeled cDNA for TIMP-1 or TIMP-2 and rehybridized with a CDNA probe for GAPDH, as internal control, to verify RNA loads. C, Aliquots of equal amounts of conditioned media based on cell numbers from cells cultured in $5 \mathrm{~mm}(L)$ or $25 \mathrm{~mm}(H)$ glucose were concentrated and analyzed on $10 \%$ SDS-polyacrylamide gel under reducing conditions. Electrophoretically transferred proteins were immunoblotted using primary antibodies against TIMP-1 and TIMP-2. Results from both Northern and Western blottings were analyzed by densitometry ( $B$ and $D$, respectively). Expression in $5 \mathrm{~mm}$ glucose was plotted as $100 \%$. Each bar represents the mean \pm SD of three independent experiments. Differences were significant at $p<0.05$.

blot analysis (Fig. 8, C and D). Cells grown in high glucose concentration revealed an increase by $35 \%$ for TIMP-1 protein in a single 28-kd band compared with cells grown in control media. In contrast, the single 22-kd TIMP-2 immunoreactive band was reduced by $35 \%$ in high glucose conditioned medium when compared with the control (Fig. 8, C and D).

To examine the possible role of integrins in transcriptional regulation and secretion of MMPs in HK-2 cells, cells were cultured in the presence of mAbs 
against $\alpha 3$ (P1B5), $\beta 1$ (P5D2), $\alpha 3$ and $\beta 1$ simultaneously, $\alpha \vee \beta 3$ (Lm609), and HLA (W6/32), which was used as a control, or in the absence of antibody, for 72 hours at $37^{\circ} \mathrm{C}$ as described in "Materials and Methods." Conditioned media were collected for zymography. As shown in Figure 9, $A$ and $B$, in the presence of either anti- $\alpha 3 \mathrm{mAb}$ or anti- $\beta 1 \mathrm{mAb}$, a $70 \%$ increase each in the secretion of MMP-2 was observed, whereas the combination of these two mAbs increased the secretion of MMP-2 approximately 2.4fold in comparison with untreated cells or cells incubated with a control antibody (W6/32). mAbs against $\alpha 3$ and $\beta 1$ integrins either alone or combined did not significantly affect the secretion of MMP-9. Additionally, we examined the effect of anti- $\alpha 3$ and anti- $\beta 1$ mAbs on the expression of MMP-2 mRNA. Northern blot analysis revealed that in the presence of either $\mathrm{mAb}$ against $\alpha 3$ integrin or $\beta 1$ integrin alone, an up-regulation of MMP-2 expression was observed, $70 \%$ and $60 \%$, respectively. When cells were treated with a combination of $\mathrm{mAb}$ against $\alpha 3$ and $\beta 1$ integrin subunits, an approximately 2 -fold increase of MMP-2 mRNA was observed in comparison with untreated controls (Fig. 9, C and D). These data suggested a cooperative effect of the two different integrin subunits.
Incubation of HK-2 in the presence of $\mathrm{mAb}$ against the $\alpha \vee \beta 3$ integrin resulted in a dramatic decrease (approximately 6.5-fold) of MMP-9 secretion in zymography (Fig. 10, A and B) and Western blot analysis (Fig. 10, C and D). In contrast, MMP-2 secretion was unaltered by treatment of the cells with $\mathrm{mAb}$ against the $\alpha v \beta 3$ integrin, in comparison with that of cells incubated with a control antibody (anti-HLA) or in the absence of antibody (Fig. 10A). These observations suggested that $\alpha \vee \beta 3$ participates in down-regulation of MMP-9.

\section{Discussion}

In diabetes, hyperglycemia alters cell behavior in vitro or in situ as a result of elevated glucose concentrations or other mechanisms. In the present report we provide evidence that increased glucose levels affect cell behavior by modulating the expression and function of integrins in cultured human proximal tubular epithelial cells, the HK-2 cells. The observed changes were not due to osmotic effects of glucose, because incubation of HK-2 cells in the presence of L-glucose did not result in integrin differences from control cells, which were grown in $5 \mathrm{~mm}$ glucose, by either FACs or Western analysis (data not shown). In addition, in a different report, L-glucose had no effect in cultured primary tubular epithelial cells (Park and Han, 2002).

HK-2 cells grown in normal $(5 \mathrm{~mm})$ glucose concentration mainly expressed $\alpha 3 \beta 1$ and $\alpha v \beta 3$ integrins. These integrins were reported to be present in situ in

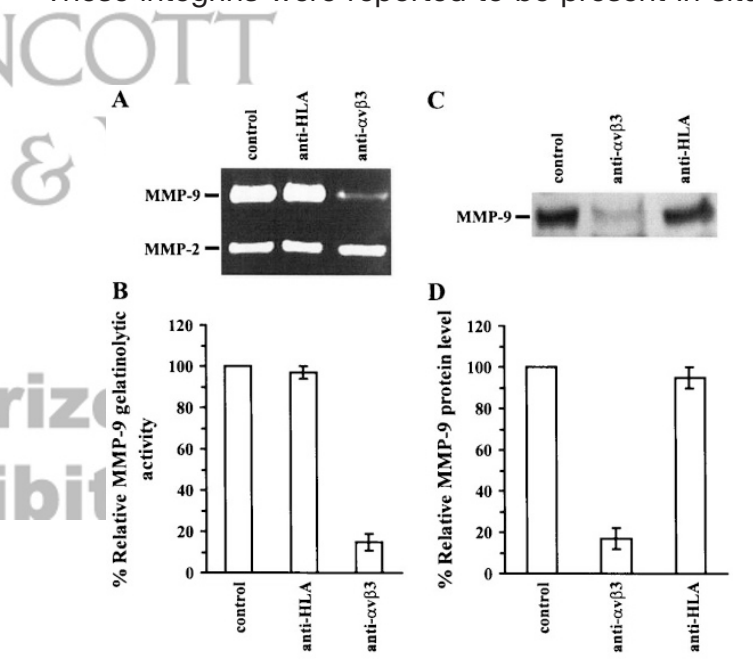

Figure 9.

Effect of anti- $\alpha 3$ and anti- $\beta 1$ antibodies on MMP-2 and MMP- 9 expression and secretion. HK-2 cells were preincubated in the absence or presence of mAbs, anti- $\alpha 3$ integrin $\mathrm{mAb}$ (P1B5), anti- $\beta 1$ integrin $\mathrm{mAb}$ (P5D2), a combination of both anti- $(\alpha 3+\beta 1)$ integrin mAbs, and anti-HLA mAb (W6/32) as a negative control, at a concentration of $40 \mu \mathrm{g} / \mathrm{ml}$ each in culture medium, for 30 minutes at $37^{\circ} \mathrm{C}$, and then diluted 10 -fold to a final concentration of $4 \mu \mathrm{g} / \mathrm{ml}$ each and cultured for 48 hours. The medium was removed, the flasks were washed with PBS, and cells were incubated for 24 hours in medium lacking BPE, containing or not $4 \mu \mathrm{g} / \mathrm{ml}$ of each mAb. At the end of the 24-hour incubation period, aliquots of equal amounts of conditioned media based on cell numbers were concentrated and analyzed by gelatin zymography (A) and $20 \mu \mathrm{g}$ of total RNA isolated from cells in each condition were probed with DIG-labeled CDNA for MMP-2 and rehybridized with a cDNA probe for GAPDH, as internal control, to verify RNA loads (C). Results from both gelatin zymography and Northern blotting were analyzed by densitometry (Panels B and D, respectively). Gelatinolytic activity and expression in the absence of antibody (control) were plotted as $100 \%$. Each bar represents the mean \pm so of three independent experiments. Differences were significant at $p<0.05$.

\section{Figure 10.}

Effect of anti- $\alpha v \beta 3$ antibody on MMP-2 and MMP-9 secretion. HK-2 cells were preincubated with mAbs, anti- $\alpha \mathrm{V} \beta 3$ integrin mAb (Lm609), anti-HLA mAb (W6/32), at a concentration of $40 \mu \mathrm{g} / \mathrm{ml}$ each in culture medium, for 30 minutes at $37^{\circ} \mathrm{C}$, and then diluted 10 -fold to a final concentration of $4 \mu \mathrm{g} / \mathrm{ml}$ each, and cultured for 48 hours. As an additional control, the cells were incubated in the absence of antibodies. At the end of the incubation, the medium was removed, the flasks were washed with $1 \times$ PBS, and cells were incubated for 24 hours in medium lacking BPE, containing or not $4 \mu \mathrm{g} / \mathrm{ml}$ of each mAb. After 24 hours, aliquots of equal amounts of conditioned media based on cell numbers were concentrated and analyzed by gelatin zymography (A) and Western blotting $(C)$. Results from gelatin zymography and Western blotting were analyzed by densitometry ( $B$ and $D$, respectively). Gelatinolytic activity and expression in the absence of antibody (control) were plotted as $100 \%$. Each bar represents the mean \pm SD of three independent experiments. Differences were significant at $p<0.05$. 
kidney proximal tubules (Simon and McDonald, 1990), as well as in a primate kidney tubular epithelial cell line (Gailit et al, 1993). In renal tubular epithelial cells, the $\alpha 3 \beta 1$ integrin mediates binding to laminin and fibronectin and the $\alpha \mathrm{v} \beta 3$ integrin binds to collagen and fibronectin (Goligorsky et al, 1993). Both the $\alpha 3 \beta 1$ and $\alpha \vee \beta 3$ integrins of $\mathrm{HK}-2$ cells bind to tubulointerstitial nephritis antigen (TIN-ag), a specialized component of TBM (Chen et al, 1996). In addition, HK-2 cells express $\alpha 5$ and $\alpha 2$ integrins, which also mediate binding to collagens, laminin, and fibronectin. In our experiments, when the cells were cultured in the presence of $25 \mathrm{~mm}$ glucose, a decrease of the $\alpha 3, \alpha 5, \alpha \vee \beta 3$, and $\beta 1$ integrin subunits was observed, with a concomitant increase in $\alpha 2$ subunit compared with control cells. This "integrin reversal" has also been reported in other cell types. Human mesangial and glomerular epithelial cells grown in $25 \mathrm{~mm}$ glucose revealed an increased expression of some integrins with concomitant decrease of others, which led to altered functions of these integrins, including impaired interactions with collV (Kitsiou et al, unpublished data; Setty et al, 1995). In addition, modulation of integrin expression has been reported to occur in different stages of cell differentiation (Adams and Watt, 1990; Rozzo et al, 1993), in human glomerular diseases (Hafdi et al, 2000), and in human umbilical vein endothelial cells cultured in high glucose (Roth et al, 1993). In these situations, cells responded to the altered milieu by modulating their integrin pattern.

The observed modulation of integrin expression in HK-2 cells reflected altered interactions with major TBM macromolecules, such as collV and laminin. HK-2 cells grown in high glucose $(25 \mathrm{~mm})$ adhered more to both substrates than cells grown in low glucose (5 mM), in solid phase adhesion assays. Another cell type, glomerular epithelial cells, were observed to adhere to a lesser extent to BM substrates in the presence of high glucose (Kitsiou et al, unpublished data). Thus, modulation of adhesion in the presence of increased glucose concentrations is cell type-specific. Moreover, cells preferentially adhered to collV compared with laminin for both concentrations of glucose.

HK-2 cells used different integrins to bind to collV and laminin and, in addition, in the presence of high glucose the integrin repertoire involved in the binding events differed, compared with the binding in low glucose. Experiments of inhibition of adhesion using anti-integrin mAbs demonstrated that HK-2 cells grown under normal glucose concentrations used primarily the $\alpha \vee \beta 3$ integrin for adhesion to collV. In addition, these cells apparently used $\beta 1$ combined with $\alpha$ subunits, including $\alpha 5 \beta 1$, but to a lesser extent than $\alpha \vee \beta 3$. In high glucose concentrations, the cells used $\alpha \vee \beta 3$, albeit to a lesser extent than in $5 \mathrm{~mm}$ glucose, as well as $\alpha 5 \beta 1$ and $\alpha 2 \beta 1$. This was suggested by the extent of inhibition of cell adhesion to collV in high glucose, which corroborated the observed changes of $\alpha \mathrm{v} \beta 3$ and $\alpha 2 \beta 1$ integrins compared with the control, because elevated glucose resulted in increased expression of $\alpha 2$ with a concomitant de- crease of $\alpha \vee \beta 3$ integrins. Inhibition experiments on laminin substrates revealed that $\beta 1$-mediated adhesion in $5 \mathrm{~mm}$ glucose did not primarily involve the $\alpha 5$ or $\alpha 2$ integrin subunits, because the observed inhibition in the presence of anti- $\alpha 5$ or anti- $\alpha 2$ antibodies was minimal. It is possible that other " $\alpha$ " integrin subunits, such as the $\alpha 3$ may be responsible for this interaction in proximal tubular epithelial cells, as was reported previously (Goligorsky et al, 1993). mAb against $\alpha v \beta 3$ resulted in a small inhibition of adhesion, suggesting that this integrin should play a minor role in HK-2 cell adhesion to laminin. In the presence of high glucose, in addition to $\beta 1, \alpha 2$ and $\alpha \mathrm{v} \beta 3$ integrins were apparently used for adhesion to laminin. The above data indicate that glucose-induced alteration of integrin expression in HK-2 cells was accompanied by altered integrin functions, including cell-matrix interactions. Our observations suggest that different integrin subunits play a dominant role in the binding of $\mathrm{HK}-2$ cells to collV and laminin, depending on glucose concentration. If similar changes occur in situ in diabetes, then altered interactions with matrix components could be responsible for altering integrin-mediated intracellular signaling and matrix-related gene expression.

Thickening of TBM is one of the characteristic changes occurring in DN (Brito et al, 1998), possibly due to increased deposition (synthesis and accumulation) and/or decreased degradation of ECM macromolecules (Lane et al, 1993; Phillips et al, 1997; Ziyadeh, 1993). In this respect, our results demonstrated that HK-2 cells grown in $25 \mathrm{~mm}$ glucose underwent changes resulting in altered expression and/or activity of matrixins/MMPs. Exposure of cells to elevated glúcóse levels resulted in a downregulation of both MMP-2 and MMP-9 enzymes with a concomitant up-regulation of the inhibitor TIMP-1, which is specific for MMP-9. The observed decrease of TIMP-2, specific inhibitor for MMP-2, may represent a balancing cellular effect to decreased MMP levels. Similar observations have been reported for other cell types; increased glucose concentrations resulted in altered expression of matrix, MMPs and TIMPs (Anderson et al, 1996; Kitsiou et al, unpublished data; Leehey et al, 1995), and kidneys of streptozotocindiabetic rats (Wu et al, 1997). Our results indicate that high glucose levels cause changes in HK-2 function, which in turn could contribute to the decreased degradation of the ECM proteins. The long-term effect could be matrix accumulation, which is typical of the thickening of TBM in DN.

It has been previously reported that integrins may have a significant role in MMP-dependent degradation of ECM, regulating the expression and activation of these enzymes. In synovial fibroblasts, $\alpha 5 \beta 1$ and $\alpha 4 \beta 1$ were shown to regulate MMP-2 and stromelysin expression (Huhtala et al, 1995; Werb et al, 1989), and $\alpha 2 \beta 1$ integrin was observed to mediate the induction of MMP-1 in fibroblasts (Langholz et al, 1995). Expression and secretion of MMP-2 was modulated by $\alpha \vee \beta 3$ and $\alpha 5 \beta 1$ integrins (Seftor et al, 1992, 1993), and expression of $\alpha \mathrm{v} \beta 3$ correlated with activation of 
MMP-2 in human melanoma cells (Hofmann et al, 2000). In addition, the $\alpha 2 \beta 1$ integrin was reported as a positive regulator of the expression of MMP-1 in osteosarcoma cells (Riikonen et al, 1995), and $\alpha 3 \beta 1$ integrin induced the expression of MMP-9 in human and mouse keratinocytes (DiPersio et al, 2000; Larjava et al, 1993). Chintala et al (1996) have reported that antibody-induced ligation of $\alpha 3 \beta 1$ and $\alpha 5 \beta 1$ integrin enhanced the secretion of MMP-2 in glioblastoma cells, whereas $\alpha 3 \beta 1$ and $\alpha 5 \beta 1$ integrins may be involved in the induction of expression/secretion and activation of MMP-2 in rhabdomyosarcoma and fibrosarcoma cells, respectively (Kubota et al, 1997; Stanton et al, 1998). Furthermore, several other recent reports have implicated $\alpha 3 \beta 1, \alpha 4 \beta 1, \alpha 5 \beta 1$, and $\alpha \vee \beta 6$ integrins in the regulation of MMP-2 and MMP-9 expression and secretion in various cell types (Agrez et al, 1999; Esparza et al, 1999; Sugiura and Berditchevski, 1999; Xie et al, 1998). Our results demonstrated that ligation of $\alpha 3 \beta 1$ integrin with mAbs, which in this case mimicked the effect of integrin ligands, resulted in the induction of the expression and secretion of matrixin MMP-2; mAbs against $\alpha \mathrm{v} \beta 3$ had no significant effect. This integrin-mediated mechanism of MMP-2 regulation of expression should involve FAK phosphorylation (Kitsiou et al, unpublished data), as well as MAPK activation, as we and others reported elsewhere (Krishnamurti et al, 1997, Tremble et al, 1995). In this respect, the observed decrease of $\alpha 3 \beta 1$ in high glucose should also account for the decreased expression of MMP-2, at least in part. In contrast, ligation of $\alpha v \beta 3$ but not $\alpha 3 \beta 1$ resulted in an impressive down-regulation of MMP-9 secretion. The mechanism by which ligation of $\alpha \vee \beta 3$ resulted in down-regulation of MMP-9 is not fully understood. However, regulation of gene expression by integrins involves multiple and complex mechanisms in which signals from integrins and growth factor receptors and signals involving PI-3 kinase and other kinases cross talk, resulting in positive or negative regulation (Giancotti and Ruoslahti, 1999). In the case of T-lymphocytes, fibronectin induced the expression of MMP-2 and MMP-9 via $\alpha 4-$, $\alpha 5-$, and $\alpha v$-bearing integrins and transmitted both stimulatory (through Src-type tyrosine kinase) and inhibitory signals (through Ras/MAPK signaling) for both these matrixins, suggesting that their relative predominance should be regulated by additional stimuli (Esparza et al, 1999). In HK-2 cells, $\alpha 3 \beta 1$ and $\alpha v \beta 3$ integrins apparently represent major receptors with opposite effects on the expression/secretion of MMP-2 and MMP-9, although the expression of these two matrixins may be additionally regulated by other integrins or different receptors.

In conclusion, our results indicate that glucoseinduced modulation of integrin expression resulted in changes in HK-2 integrin-related functions in vitro, which in turn could contribute to the decreased degradation of matrix proteins. The long-term effect, in situ, could be matrix accumulation, which is typical of the thickening of the TBM in DN. The evidence presented in this report suggests that $\alpha 3 \beta 1$ and $\alpha \mathrm{v} \beta 3$ integrins are receptors involved in differential regula- tion of MMP-2 expression and secretion (upregulation) and MMP-9 secretion (down-regulation), respectively, and that glucose-induced alterations of integrins and integrin-related functions in cells grown in high glucose concentrations may be mechanistically linked to the observed alterations in the expression and secretion of matrixins.

\section{Materials and Methods}

\section{Cell Lines and Culture Conditions}

Human proximal tubular epithelial cells, HPV-16 immortalized (HK-2) (Ryan et al, 1994), were cultured in keratinocyte serum-free medium (KSF-M; Gibco BRL Life Technologies, Grand Island, New York), supplemented with epidermal growth factor (EGF; $10 \mathrm{ng} / \mathrm{ml}$ ) and bovine pituitary extract (BPE; $40 \mu \mathrm{g} / \mathrm{ml}$ ), in either 5 or $25 \mathrm{~mm} \mathrm{D-glucose,} \mathrm{at} 37^{\circ} \mathrm{C}$ in an environment of $95 \%$ air and $5 \% \mathrm{CO}_{2}$. Cells were released from their tissue culture flasks for passaging or use in experiments by treatment with $0.05 \%$ trypsin/ 1 mM EDTA. For experiments, cells were cultured for at least three passages. For the adhesion and inhibition of adhesion experiments, HK-2 cells were grown in either 5 or 25 mm glucose in T-25 flasks until $75 \%$ to $80 \%$ confluency was reached and were metabolically labeled for 18 hours with $0.15 \mathrm{mCi}$ of $\left.{ }^{35} \mathrm{~S}\right]$-methionine (Amersham, London, England) per T-25 flask, in medium lacking BPE.

For zymography and Western blotting analysis of conditioned media, cells $\left(2 \times 10^{6}\right)$ were cultured in either 5 or $25 \mathrm{~mm}$ glucose media in $75 \mathrm{~cm}^{2}$-tissue culture flasks for 48 hours. The medium was then removed, the flasks were washed three times with PBS, and cells were incubated for 24 hours in $10 \mathrm{ml}$ medium lacking BPE. At the end of the 24-hour incubation period, the conditioned media were transferred to $15 \mathrm{ml}$ conical tubes, centrifuged to remove cells and cell fragments, supplemented with $1 \mathrm{~mm}$ $\mathrm{Na}_{2}$ EDTA and $0.02 \%$ sodium azide, and stored at $-20^{\circ} \mathrm{C}$ for further use.

\section{Antibodies}

Rabbit anti-human polyclonal antibodies to the integrin subunits $(\alpha 2, \alpha 3, \alpha 5, \alpha v, \beta 1$, and $\beta 3)$ and mouse anti-human mAbs against $\alpha 2$ (P1E6), $\alpha 3$ (P1B5), $\alpha 5$ (P1D6), $\alpha \vee \beta 3$ (Lm609), and $\beta 1$ (P5D2) integrin subunits, which have been previously characterized (Wayner et al, 1991, 1993), were obtained from Chemicon International (Temecula, California). Rabbit polyclonal antibodies against collagenases MMP-2 (Ab45) and MMP-9 (Ab110) and their inhibitors TIMP-1 and TIMP-2 were kindly provided by Dr. StetlerStevenson. Anti-HLA mAb (W6/32) was used as control (W6/32, HB95; American Type Culture Collection, Rockville, Maryland). Mouse anti-tubulin mAb was purchased from Sigma (St. Louis, Missouri). Fluorescein-conjugated goat anti-mouse IgG was obtained from Cappel (ICN Pharmaceuticals, Frankfurt, Germany). 


\section{Preparation of Substrates}

CollV and laminin were isolated from EHS tumor (Orkin et al, 1977), grown subcutaneously in lathyritic mice, and purified according to previously described protocols (Charonis et al, 1985; Kleinman et al, 1982). Before use, collV was dialyzed against PBS ( $\mathrm{pH} 7.4)$, and cleared of large aggregates by centrifugation at $14,000 \mathrm{rpm}$ for 30 minutes at $4^{\circ} \mathrm{C}$. Protein concentration was determined using the method of Waddell (Waddell, 1956; Wolf, 1983). Laminin was dialyzed twice against $50 \mathrm{~mm}$ Tris- $\mathrm{HCl}(\mathrm{pH} 7.6)$, overnight against $50 \mathrm{~mm}$ Tris- $\mathrm{HCl}, 1 \mathrm{M} \mathrm{CaCl}_{2}(\mathrm{pH} 7.6)$, and again with $50 \mathrm{~mm}$ Tris- $\mathrm{HCl}(\mathrm{pH}$ 7.6). Laminin concentration was determined by the method of Bradford using a Coomassie Plus Protein Assay Reagent Kit (Pierce, Rockford, Illinois).

\section{Cell Adhesion to CollV and Laminin}

Ninety-six-well microtiter plates (Microlon 600; Greiner Japan, Tokyo, Japan) were coated with $50 \mu \mathrm{l}$ of collV and laminin in serial dilutions starting from 100 $\mu \mathrm{g} / \mathrm{ml}$. The microtiter plates were allowed to evaporate at $29^{\circ} \mathrm{C}$ to dryness. To block the remaining reactive sites, the plates were treated with $200 \mu \mathrm{l}$ of BSA at $2 \mathrm{mg} / \mathrm{ml}$ in PBS (pH 7.4) and incubated for 2 hours at $37^{\circ} \mathrm{C}$. Plates were then washed once with $200 \mu \mathrm{l}$ of sterile PBS and immediately used for experiments. Labeled cells were detached from the flasks by incubation with trypsin, washed twice with DMEM, and resuspended in binding buffer (DMEM, $2 \mathrm{mg} / \mathrm{ml}$ BSA, 15 mm HEPES, pH 7.5). Fifty microliters of cell suspension, containing 5,000 cells, were added per well and the plates were incubated for 60 minutes at $37^{\circ} \mathrm{C}$ in a humidified incubator. After incubation, the cells were washed three times with $200 \mu$ l of binding buffer to remove nonadherent cells and $100 \mu$ l of lysis buffer $(0.5 \mathrm{NaOH}, 1 \% \mathrm{SDS})$ were added to each well. The lysate was transferred to scintillation vials and counted. Total input counts per minute was $50 \mu \mathrm{l}$ of cell suspension (5,000 cells) added to scintillation vials. The data were expressed as a percentage of the total input counts per minute to give percentage adhesion. Nonspecific adhesion of cells to BSA was subtracted from the percentage adhesion to adhesive proteins. Cell adhesion assays were performed at least three times in hexaplicate.

\section{Inhibition of Cell Adhesion to CollV and Laminin}

Ninety-six-well microtiter plates (Microlon 600; Greiner) were coated with $50 \mu \mathrm{l}$ of collV and laminin at $10 \mu \mathrm{g} / \mathrm{ml}$ and $12 \mu \mathrm{g} / \mathrm{ml}$, respectively, overnight at $29^{\circ} \mathrm{C}$. The plates were blocked with $200 \mu \mathrm{l}$ of $2 \mathrm{mg} / \mathrm{ml}$ BSA/PBS for 2 hours at $37^{\circ} \mathrm{C}$, washed once with sterile PBS, and then $10 \mu \mathrm{g} / \mathrm{ml}$ of $\mathrm{mAb}$ to integrin subunit or mAb to HLA were added to each well at a final volume of $100 \mu \mathrm{l} /$ well, followed immediately by the cells. Cells were processed as for the adhesion assay and $50 \mu \mathrm{l}$ of cell suspension in binding buffer (5,000 cells) were added to each well. Cells were allowed to adhere for 60 minutes at $37^{\circ} \mathrm{C}$ in a humid- ified incubator, then washed three times with binding buffer to remove nonadherent cells, and bound cells were quantified as described previously. The concentration of antibodies used in inhibition assays was well above the saturating concentration as determined by flow cytometry. Data were expressed as the percentage of adhesion observed in the absence of antibody. Inhibition experiments were performed at least three times in hexaplicate.

\section{FACS}

Expression of integrin subunits in cultured HK-2 cells was evaluated by indirect immunofluorescence staining and FACS. Briefly, HK-2 cells were released from confluent monolayer cultures with trypsin, washed, and resuspended in FACS buffer (2\% FCS, $0.02 \%$ sodium azide in PBS). Cells $\left(5 \times 10^{5}\right)$ were added to each vial and incubated with mAbs to $\alpha 2, \alpha 3, \alpha v \beta 3$, $\beta 1$, and HLA (used as a control) for 45 minutes on ice and washed twice with $2 \mathrm{ml}$ FACS buffer. Then, goat anti-mouse IgG-conjugated with FITC was added in a total volume of $0.1 \mathrm{ml}$ FACS buffer, and cells were incubated for 45 minutes on ice. After washing twice with FACS buffer, the cells were fixed with $1 \mathrm{ml}$ of $1 \%$ formaldehyde in PBS. Analysis was performed using CELL QUEST software on a FACScan (Becton Dickinson, Franklin Lakes, New Jersey). Positive fluorescence was determined on a four-decade log scale and fluorescence (log F1) was expressed as the mean channel number of 10,000 cells.

\section{Incubation of Cells with Antibodies}

HK-2 cells were detached from confluent monolayer cultures by trypsin treatment, collected by centrifugation, and resuspended in culture medium $\left(2.5 \times 10^{6}\right.$ cells $/ \mathrm{ml}$ ) in normal glucose concentration ( $5 \mathrm{~mm}$ ). After addition of anti-integrin $\mathrm{mAb}$ at a concentration of 40 $\mu \mathrm{g} / \mathrm{ml}$ each, cells were preincubated for 30 minutes at $37^{\circ} \mathrm{C}$, and then diluted 10 -fold to a final concentrations of $4 \mu \mathrm{g} / \mathrm{ml}$ each, or in the absence of antibody, and cultured for 48 hours. The medium was then removed, the flasks were washed three times with PBS, and cells were incubated for 24 hours in medium lacking BPE containing or not $4 \mu \mathrm{g} / \mathrm{ml}$ of each $\mathrm{mAb}$. After 24 hours, the conditioned media were collected for zymography and Western blotting, and the cells counted and used for RNA isolation.

\section{cDNA Probes}

The following probes were used: pBSK plasmids containing 1.8-kb Pst fragment from $\alpha 3$ cDNA integrin subunit, 299-bp EcoRI fragment from MMP-2 cDNA, 490-bp and 600-bp EcoRI/BamHI fragments from TIMP-2 and glyceraldehyde-3-phosphate dehydrogenase (GAPDH) cDNA, and a 450-bp EcoRI/HindIII fragment from TIMP-1 cDNA. Finally, a 1.3-kb fragment of $\beta 1$ integrin subunit was used, which was cloned into PECE plasmid at a $\mathrm{Bg} / \mathrm{ll}$ site. $\mathrm{CsCl}$ purified plasmids containing the cDNA inserts were isolated and digested by appropriate restriction enzymes. The 
cDNA inserts were separated by electrophoresis in $1 \%$ low-melting agarose gels and they were purified from agarose slices by phenol-chloroform extraction. Inserts were labeled with digoxigenin-11dUTP using the DIGHigh Prime DNA Labeling and Detection Starter Kit II (Boehringer-Mannheim, Mannheim, Germany).

\section{Total RNA Isolation and Northern Blot Analysis}

Total cellular RNA was isolated from HK-2 cells cultured in either low $(5 \mathrm{~mm})$ or high $(25 \mathrm{~mm})$ glucose, as well as in the presence of anti-integrin mAbs, using the RNAgents Total RNA Isolation System (Promega, Southampton, England) according to the manufacturer's instructions. The concentration and purity of RNA was determined spectrophotometrically by reading the absorbance at $260 \mathrm{~nm}$ and $280 \mathrm{~nm}$. Twenty micrograms of RNA from each sample were denatured in $1 \times$ MOPS buffer $(20 \mathrm{~mm}$ 3-N-morpholinopropanesulphonic acid, $8 \mathrm{~mm}$ sodium acetate, $1 \mathrm{~mm}$ EDTA, pH 7) containing $2.2 \mathrm{~m}$ formaldehyde and $50 \%$ formamide by heating at $65^{\circ} \mathrm{C}$ for 15 minutes. Samples were then mixed with 10x loading buffer $(50 \%$ glycerol, $0.25 \%$ bromophenol blue, $0.25 \%$ xylene cyanol FF, $1 \mathrm{~mm}$ EDTA) in $1 \times$ final concentration, and separated in $1 \%$ agarose gel containing formaldehyde for 3 hours at 4 Volts/cm in $1 \times$ MOPS running buffer containing $2.2 \mathrm{~m}$ formaldehyde. RNAs were transferred overnight from the gel to Hybond- $\mathrm{N}^{+}$nylon membrane (Amersham) by capillary elution. The membranes were incubated in prehybridization solution (7\% SDS, $50 \%$ formamide, $5 \times$ SSC, $50 \mathrm{~mm}$ sodium phosphate, $0.1 \%$ L-Lauroylsarcosine, $100 \mu \mathrm{g} / \mathrm{ml}$ sonicated salmon sperm DNA, and 2\% blocking reagent) for 2 hours at $42^{\circ} \mathrm{C}$. Hybridizations were performed overnight at $42^{\circ} \mathrm{C}$ in the same solution containing $50 \mathrm{ng} / \mathrm{ml}$ of the appropriate denaturated DIG-labeled CDNA probe. After hybridization, filters were washed $2 \times 15$ minutes in $2 \times$ SSC, $0.1 \%$ SDS at room temperature, and $2 \times$ 15 minutes in $0.2 \times \mathrm{SSC}, 0.1 \% \mathrm{SDS}$ at $60^{\circ} \mathrm{C}$. Signal detection was performed using the DIG Luminescent Detection Kit (Boehringer-Mannheim), according to the manufacturer's protocol. Filters were stripped of previous probes in $2 \times$ SSC, $0.5 \%$ SDS for 20 minutes by heating at $90^{\circ} \mathrm{C}$ and reprobed with GAPDH probe as internal control. The resulting measurements were corrected for GAPDH mRNA levels.

\section{Gelatin Zymography}

Gelatin zymography was performed as previously described (Anderson et al, 1996). Briefly, aliquots of equal amounts of conditioned media, based on cell numbers determined at the time of harvest, were concentrated and subjected under nonreducing conditions and without boiling to $10 \%$ SDSpolyacrylamide gels containing $0.1 \%$ gelatin. After electrophoresis, the gel was washed three times for 30 minutes with $50 \mathrm{~mm}$ Tris- $\mathrm{HCl}, \mathrm{pH} 7.5,5 \mathrm{~mm} \mathrm{CaCl}_{2}, 1$ $\mu \mathrm{M} \mathrm{ZnCl}_{2}, 2.5 \%$ Triton $\mathrm{X}-100$, and $0.02 \% \mathrm{NaN}_{3}$ at room temperature to remove SDS. The gel was then incubated in the same buffer excluding Triton X-100 for 48 hours at $37^{\circ} \mathrm{C}$. After staining with Coomassie brilliant blue R-250 for 3 hours and destaining in water, gelatin-degrading activity was visualized as clear bands against a dark blue background.

\section{Total Protein Extraction}

HK-2 cells cultured in either low or high glucose media were detached from flasks by treatment with trypsin, washed three times with PBS ( $\mathrm{pH} 7.4)$, and lysed in a buffer containing $1 \%$ Triton $\mathrm{X}-100,1 \mathrm{~mm} \mathrm{CaCl}_{2}$, a cocktail of protease inhibitors (P8340; Sigma), $1 \mathrm{~mm}$ PMSF, 1 mM NEM in PBS ( $\mathrm{pH} 7.4$ ) for 60 minutes at $4^{\circ} \mathrm{C}$. Insoluble material was removed by centrifugation at $13,000 \mathrm{rpm}$ for 30 minutes at $4^{\circ} \mathrm{C}$. Protein estimation was done by the method of Bradford using a Coomassie Plus Protein Assay Reagent Kit (Pierce).

\section{Western Blotting}

Equal protein amounts from cell lysates were separated by $7.5 \%$ SDS-polyacrylamide gel electrophoresis, under nonreducing conditions according to the method of Laemmli (1970). For MMPs and TIMPs, equal amounts of condition media (based on cell number) were concentrated and separated by $10 \%$ SDS-PAGE, under reducing conditions. After electrophoresis, proteins were transferred to Hybond-ECL nitrocellulose membrane (Amersham) by electroblotting (Towbin et al, 1979) and blots were blocked for 2 hours at room temperature with $5 \%$ nonfat milk in TBS, with $0.1 \%$ Tween-20. Membranes were then incubated overnight at $4^{\circ} \mathrm{C}$ with the appropriate dilutions of polyclonal antibodies or $\mathrm{mAb}$ against tubulin (used as internal control), in the same buffer without Tween-20. After washing with TBS/0.1\% Tween-20, membranes were incubated for 1 hour at room temperature with peroxidase (HRP)-conjugated anti-rabbit or anti-mouse immunoglobulins (Amersham) as secondary antibodies. Bound antibody was detected by ECL Western blotting detection system (Amersham).

\section{Statistical Analysis}

Mean values were derived from experiments performed in triplicate. These values were compared using the Student $t$ test. In adhesion experiments, a single-factor analysis of variance (ANOVA) was performed on the results for cells grown in either 5 or $25 \mathrm{~mm}$ glucose, in each substrate concentration. A $p$ value of $<0.05$ was considered statistically significant.

\section{Densitometric Analysis}

Images of Western and Northern blots as well as zymograms were analyzed using image processing software (Bioprofil Vilber Loumart, Paris, France).

\section{References}

Adams JC and Watt FM (1990). Changes in keratinocyte adhesion during terminal differentiation: Reduction in fibronectin binding precedes $\alpha 5 \beta 1$ integrin loss from the cell surface. Cell 63:425-435. 
Agrez M, Xinhua G, Turton J, Meldrum C, Niu J, Antalis T, and Howard EW (1999). The $\alpha v \beta 6$ integrin induces gelatinase $B$ secretion in colon cancer cells. Int J Cancer 81:90-97.

Anderson SS, Charonis AS, Kim Y, and Tsilibary EC (1992). Altered basement membrane structure and interaction with kidney mesangial cells following nonenzymatic glycosylation. J Am Soc Nephrol 3:625-629.

Anderson SS, Kim Y, and Tsilibary EC (1994). Effects of matrix glycation on mesangial cell adhesion, spreading and proliferation. Kidney Int 46:1359-1367.

Anderson SS, Tsilibary EC, and Charonis AS (1993). Nonenzymatic glycosylation-induced modifications of intact bovine kidney tubular basement membrane. J Clin Invest 92:30453052.

Anderson SS, Wu K, Nagase H, Stetler-Stevenson W, Kim Y, and Tsilibary EC (1996). Effect of matrix glycation on express of type IV collagen, MMP-2, MMP-9 and TIMP-1 by human mesangial cells. Cell Adhes Commun 4:89-101.

Ayo SH, Radnik RA, Garoni JA, Glass WR, and Kreisberg JI (1990). High glucose causes an increase in extracellular matrix proteins in cultured mesangial cells. Am J Pathol 136:1339-1348.

Ayo SH, Radnik RA, Glass WR, Garoni JA, Rampt ER, Appling DR, and Kreisberg JI (1991). Increased extracellular matrix synthesis and mRNA in mesangial cells grown in high-glucose medium. Am J Physiol 260:F185-F191.

Birkedal-Hansen H (1995). Proteolytic remodeling of extracellular matrix. Curr Opin Cell Biol 7:728-735.

Boudreau NJ and Jones PL (1999). Extracellular matrix and integrin signaling: The shape of things to come. Biochem J 339:481-488.

Brito PL, Fioretto P, Drummond K, Kim Y, Steffes MW, Basgen JM, Sisson-Ross S, and Mauer M (1998). Proximal tubular basement membrane width in insulin- dependent diabetes mellitus. Kidney Int 53:754-761.

Brooks PC, Stromblad S, Sanders LC, von Schalscha TL, Aimes RT, Stetler-Stevenson WG, Quigley JP, and Cheresh DA (1996). Localization of matrix metalloproteinase MMP-2 to the surface of invasive cells by interaction with integrin alpha v beta 3. Cell 85:683-693.

Charonis AS and Tsilibary EC (1992). Structural and functional changes in laminin and type IV collagen after nonenzymatic glycosylation. Diabetes 41(Suppl 2):49-51.

Charonis AS, Tsilibary EC, Yurchenco PD, and Furthmayr $\mathrm{H}$ (1985). Binding of laminin to type IV collagen: A morphological study. J Cell Biol 100:1848-1853.

Chen Q, Kinch MS, Lin TH, Burridge K, and Juliano RL (1994). Integrin-mediated cell adhesion activates mitogen-activated protein kinases. J Biol Chem 269:26602-26605.

Chen $Y$, Krishnamurti U, Wayner EA, Michael AF, and Charonis AS (1996). Receptors in proximal tubular epithelial cells for tubulointerstitial nephritis antigen. Kidney Int 49:153-157.

Chintala SK, Sawaya R, Gokaslan ZL, and Rao JS (1996). Modulation of matrix metalloprotease-2 and invasion in human glioma cells by alpha 3 beta 1 integrin. Cancer Lett 103:201-208.

Clark EA and Brugge JS (1995). Integrins and signal transduction pathways: The road taken. Science 268:233-239.
Danne T, Spiro MJ, and Spiro RG (1993). Effect of high glucose on type IV collagen production by cultured glomerular epithelial cells, endothelial and mesangial cells. Diabetes 42:170-177.

DiPersio CM, Shao M, Di Costanzo L, Kreidberg JA, and Hynes RO (2000). Mouse keratinocytes immortalized with large T antigen acquire $\alpha 3 \beta 1$ integrin dependent secretion of MMP-9/gelatinase B. J Cell Sci 113:2909-2921.

Ellerbroek SM, Fishman DA, Kearns AS, Bafetti LM, and Stack MS (1999). Ovarian carcinoma regulation of matrix metalloproteinase-2 and membrane type 1 matrix metalloproteinase through beta1 integrin. Cancer Res 59:16351641.

Esparza J, Vilardell C, Calvo J, Juan M, Vives J, UrbanoMarquez A, Yague J, and Cid MC (1999). Fibronectin upregulates gelatinase $B$ (MMP-9) and induces coordinated expression of gelatinase A (MMP-2) and its activator MT1-MMP (MMP-14) by human T lymphocyte cell lines. A process repressed through Ras/MAP kinase signaling pathway. Blood 49:2754-2766.

Gailit J, Colflesh D, Rabiner I, Simone J, and Goligorsky MS (1993). Redistribution and dysfunction of integrins in cultured renal epithelial cells exposed to oxidative stress. Am J Physiol 264:F149-F157.

Giancotti FG and Ruoslahti E (1999). Integrin signaling. Science 285:1028-1032.

Goligorsky MS, Lieberthal W, Racusen L, and Simon EE (1993). Integrin receptors in renal tubular epithelium: New insights into pathophysiology of acute renal failure. Am J Physiol 264(1Pt2):F1-F8.

Hafdi Z, Lesavre P, Nejjari M, Halbwachs-Mecarelli L, Droz D, and Noel LH (2000). Distribution of alphavbeta3, alphavbeta5 integrins and the integrin associated protein-IAP (CD47) in human glomerular diseases. Cell Adhes Commun 7:441451.

Haitoglou CS, Tsilibary EC, Brownlee M, and Charonis AS (1992). Altered cellular interactions between endothelial cells and nonenzymatically glucosylated laminin/type IV collagen. J Biol Chem 267:12404-12407.

Hofmann UB, Westphall JR, Van Kraats AA, Ruiter DJ, and Van Muijen GNP (2000). Expression of integrin $\alpha \mathrm{V} \beta 3$ correlates with activation of membrane-type matrix metalloproteinase-1 (MT1-MMP) and matrix metalloproteinase-2 (MMP-2) in human melanoma cells. Int $\mathrm{J}$ Cancer 87:12-19.

Huhtala P, Humphries MJ, McCarthy JB, Tremble PM, Werb Z, and Damsky CH (1995). Cooperative signaling by $\alpha 5 \beta 1$ and $\alpha 4 \beta 1$ integrins regulates metalloproteinase gene expression in fibroblasts adhering to fibronectin. J Cell Biol 129: 867-879.

Hynes RO (1992). Integrins: Versatility, modulation and signaling in cell adhesion. Cell 69:11-25.

Juliano RL and Haskill S (1993). Signal transduction from the extracellular matrix. J Cell Biol 120:577-585.

Kleinman HK, McGarvey ML, Liotta LA, Gehron Robey P, Tryggvason K, and Martin GR (1982). Isolation and characterization of type IV procollagen, laminin, and heparan sulfate proteoglycan from the EHS sarcoma. Biochemistry 21:61886193.

Krishnamurti U, Rondeau E, Sraer JD, Michael AF, and Tsilibary EC (1997). Alterations in human glomerular epithelial 
cells interacting with nonenzymatically glycosylated matrix. J Biol Chem 272:27966-27970.

Kubota S, Ito H, Ishibashi $Y$, and Seyama $Y$ (1997). Anti- $\alpha 3$ integrin antibody induces the activated form of matrix metalloprotease-2 (MMP-2) with concomitant stimulation of invasion through matrigel by human rhabdomyosarcoma cells. Int J Cancer 70:106-111.

Laemmli UK (1970). Cleavage of structural proteins during the assembly of the head of bacteriophage T4. Nature 227:680-685.

Lane PH, Steffes MW, Fioretto P, and Mauer SM (1993). Renal interstitial expansion in insulin-dependent diabetes mellitus. Kidney Int 43:661-667.

Langholz O, Rockel D, Mauch C, Kozlowska E, Bank I, Krieg T, and Eckes B (1995). Collagen and collagenase gene expression in three-dimensional collagen lattices are differentially regulated by $\alpha 1 \beta 1$ and $\alpha 2 \beta 1$ integrins. J Cell Biol 131:1903-1915.

Larjava H, Lyons JG, Salo T, Makela M, Koivisto L, BirkedalHansen H, Akiyama SK, Yamada KM, and Heino J (1993). Anti-integrin antibodies induce type IV collagenase expression in keratinocytes. J Cell Physiol 157:190-200.

Leehey D, Song RH, Alavi N, and Singh AK (1995). Decreased degradative enzymes in mesangial cells cultured in high glucose media. Diabetes 44:929-935.

Matrisian LM (1992). The matrix-degrading metalloproteinases. Bioessays 14:455-463.

Mauer SM, Steffes MW, Ellis EN, Sutherland DER, Brown DM, and Goetz FC (1984). Structural-functional relationship in diabetic nephropathy. J Clin Invest 74:1143-1155.

Nagase H and Woessner JF (1999). Matrix metalloproteinases. J Biol Chem 274:21491-21494.

Orkin RW, Gehron P, Goodwin EB, Martin GR, Valentine T, and Swarm R (1977). A murine tumor producing a matrix of basement membrane. J Exp Med 145:204-220.

Park SH and Han HJ (2002). The mechanism of angiotensin II binding down-regulation by high glucose in primary renal proximal tubule cells. Am J Physiol Renal Physiol 282:F228237.

Paulsson M (1992). Basement membrane proteins: Structure, assembly, and cellular interactions. Crit Rev Biochem Mol Biol 27:93-127.

Phillips AO, Steadman R, Morrisey K, Martin J, Eynstone L, and Williams JD (1997). Exposure of human renal proximal tubular cells to glucose leads to accumulation of type IV collagen and fibronectin by decreased degradation. Kidney Int 52:973-984.

Rasch R (1984). Tubular lesions in streptozotocin diabetic rats. Diabetologia 27:32-37.

Riikonen T, Westermarck J, Koivisto L, Broberg A, Kahari V-M, and Heino J (1995). Integrin $\alpha 2 \beta 1$ is a positive regulator of collagenase (MMP-1) and collagen $\alpha 1(\mathrm{I})$ gene expression. J Biol Chem 270:13548-13552.

Roth T, Podesta F, Stepp MA, Boeri D, and Lorenzi M (1993). Integrin overexpression induced by high glucose and by human diabetes: Potential pathway to cell dysfunction in diabetic microangiopathy. Proc Natl Acad Sci USA 90:96409644.
Rozzo C, Ratti P, Ponzoni M, and Cornaglia-Ferraris P (1993). Modulation of $\alpha 1 \beta 1, \alpha 2 \beta 1$ and $\alpha 3 \beta 1$ integrin heterodimers during human neuroblastoma cell differentiation. FEBS Lett 332:263-267.

Ruoslahti E (1991). Integrins. J Clin Invest 87:1-5.

Ryan MJ, Johnson G, Kirk J, Fuerstenberg SM, Zager RA, and Torok-Storb B (1994). HK-2: An immortalized proximal tubule epithelial cell line from normal adult human kidney. Kidney Int 45:48-57.

Schlaepfer DD, Hanks SK, Hunter T, and Geer PV (1994). Integrin-mediated signal transduction linked to Ras pathway by Grb2 binding to focal adhesion kinase. Nature 372:786791.

Seftor RE, Seftor EA, Gehlsen KR, Stetler-Stevenson WG, Brown PD, Ruoslahti E, and Hendrix MG (1992). Role of the $\alpha \vee \beta 3$ integrin in human melanoma cell invasion. Proc Nat Acad Sci USA 89:1557-1561.

Seftor RE, Seftor EA, Stetler-Stevenson WG, and Hendrix MG (1993). The $72 \mathrm{kDa}$ type IV collagenase is modulated via differential expression of alpha $v$ beta 3 and alpha 5 beta 1 integrins during human melanoma cell invasion. Cancer Res 53:3411-3415.

Setty S, Anderson SS, Wayner EA, Kim Y, Clegg DO, and Tsilibary EC (1995). Glucose-induced alteration of integrin expression and function in cultured human mesangial cells. Cell Adhes Commun 3:187-200.

Simon EE and McDonald JA (1990). Extracellular matrix receptors in the kidney cortex. Am J Physiol 259:F783-F792.

Stanton H, Gavrilovic J, Atkinson SJ, d'Ortho M-P, Yamada KM, Zardi L, and Murphy G (1998). The activation of proMMP-2 (gelatinase A) by HT1080 fibrosarcoma cells is promoted by culture on a fibronectin substrate and is concomitant with an increase in processing of MT1-MMP (MMP-

14) to a $45 \mathrm{kDa}$ form. J Cell Sci 111:2789-2798.

Steffes MW, Bilous RW, Sutherland DER, and Mauer SM (1992). Cell and matrix components of the glomerular mesangium in type I diabetes. Diabetes 41:679-684.

Steffes MW, Osterby R, Chavers B, and Mauer SM (1989). Mesangial expansion as a central mechanism for loss of kidney function in diabetes. Diabetes 38:1077-1081.

Sugiura T and Berditchevski F (1999). Function of $\alpha 3 \beta 1$ tetraspanin protein complexes in tumor cell invasion. Evidence for the role of the complexes in production of matrix metalloproteinase 2 (MMP-2). J Cell Biol 146:1375-1389.

Towbin H, Staehelin T, and Gordon J (1979). Electrophoretic transfer of proteins from polyacrylamide gels to nitrocellulose sheets. Procedure and some applications. Proc Natl Acad Sci USA 76:4350-4354.

Tremble P, Damsky CH, and Werb Z (1995). Components of the nuclear signaling cascade that regulate collagenase gene expression in response to integrin-derived signals. J Cell Biol 129:1707-1720.

Tsilibary EC, Charonis AS, Reger LA, Wohlhueter RM, and Furcht LT (1988). The effect of nonenzymatic glycosylation on the binding of the main noncollagenous NC1 domain to type IV collagen. J Biol Chem 263:4302-4308.

Waddell NJ (1956). A simple ultraviolet spectrophotometric method for the determination of protein. $\mathrm{J}$ Lab Clin Med 48:311-314. 
Wayner EA, Gil SG, Murphy GF, Wilke MS, and Carter WG (1993). Epiligrin, a component of epithelial basement membranes, is an adhesive ligand for $\alpha 3 \beta 1$ positive T lymphocytes. J Cell Biol 121:1141-1152.

Wayner EA, Orlando RA, and Cheresh DA (1991). Integrins $\alpha \vee \beta 3$ and $\alpha \vee \beta 5$ contribute to cell attachment to vitronectin but differentially distribute on the cell surface. J Cell Biol 113:919-929.

Werb Z (1997). ECM and cell surface proteolysis: regulating cellular ecology. Cell 91:439-442.

Werb Z, Tremble PM., Behrendtsen O, Crowley E, and Damsky CH (1989). Signal transduction through the fibronectin receptor induces collagenase and stromelysin gene expression. J Cell Biol 109:877-889.

Wolf P (1983). A critical reappraisal of Waddell's technique for ultraviolet spectrophotometric protein estimation. Anal Biochem 129:145-155.
Wu K, Setty S, Mauer SM, Killen P, Nagase H, Michael AF, and Tsilibary EC (1997). Altered kidney matrix gene expression in early stages of experimental diabetes. Acta Anat 158:155-165.

Xie B, Laouar A, and Huberman E (1998). Fibronectinmediated cell adhesion is required for induction of $92-\mathrm{kDa}$ type IV collagenase/gelatinase (MMP-9) gene expression during macrophage differentiation. J Biol Chem 273:1157611582.

Ziyadeh FN (1993). Renal tubular basement membrane and collagen type IV in diabetes mellitus. Kidney Int 43:114-120.

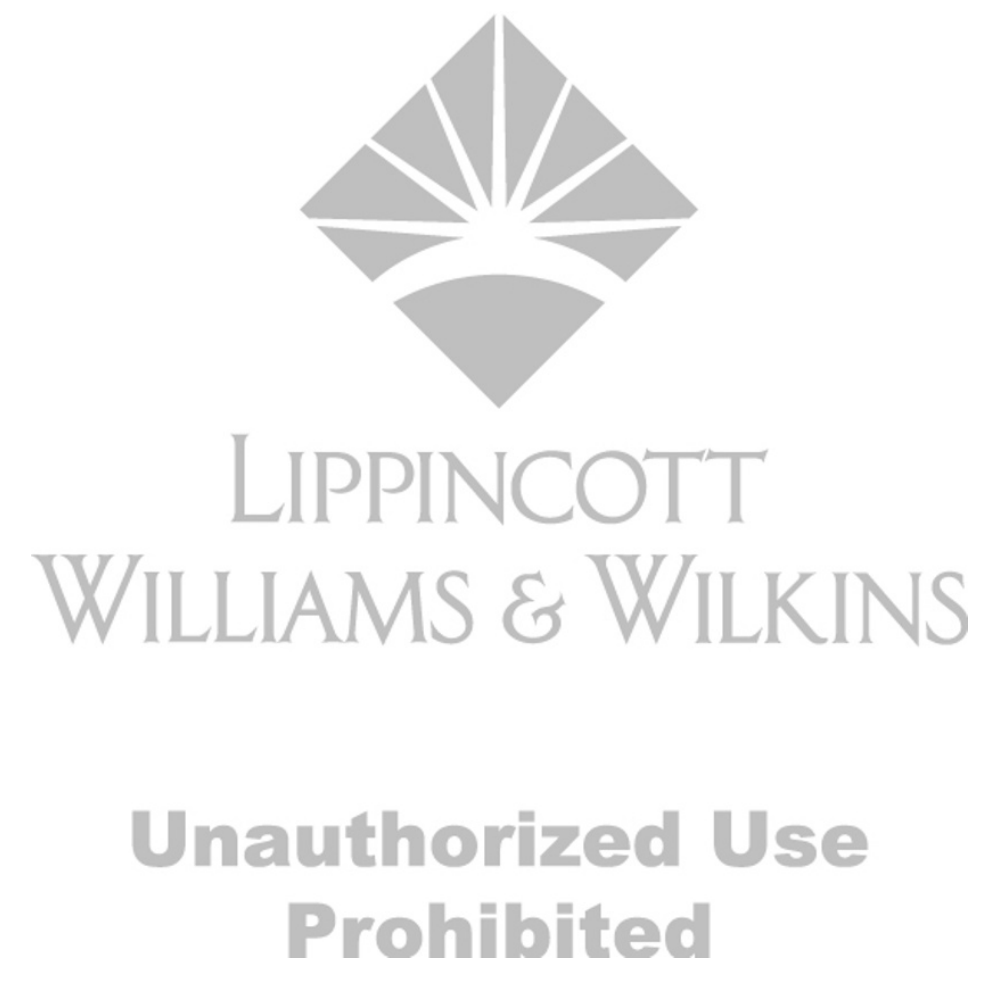

